УДК 159.923.38(043.3)

DOI https://doi.org/10.26661/2310-4368/2021-2-1

\title{
ПСИХОЛОГІЧНА СПЕЦИФІКА МУЗИКАНТА-ПРОФЕСІОНАЛА
}

\author{
Аршава I. Ф. \\ доктор психологічних наук, професор, \\ завідувач кафедри загальної психологї та патопсихології \\ Дніпровський національний університет імені Олеся Гончара \\ пр. Гагаріна, 72, Дніпро, Україна \\ orcid.org/0000-0003-1672-4479 \\ iarshava55@gmail.com
}

Новіков Ю. М.

ректор, професор, заслужений діяч мистеитв Украйни

Дніпровська академія музики імені Михайла Глінки

вул. Ливарна, 10, Дніпро, Украӥна

Кутспова-Бредун В. Ю.

кандидат психологічних наук, доиент кафедри загальної психології та патопсихології Дніпровський начіональний університет імені Олеся Гончара

пр. Гагаріна, 72, Дніпро, Украӥна

orcid.org/0000-0002-6137-815X

viluta15@i.ua

\begin{abstract}
Ключові слова: особистість музиканта (професіонала, аматора), психологічне благополуччя, стан «потоку», адаптивність
\end{abstract}

Професія музиканта посідає особливе місце у сучасному суспільстві. Гра на музичному інструменті вимагає для своєї реалізації не тільки високої професійної майстерності, але й необхідних для оволодіння будь-якою складною діяльністю вольових зусиль і мотивації. Представлено теоретичний та емпіричний аналіз психологічних особливостей музикантів-професіоналів. Досліджено особливості особистості музикантів за допомогою моделі «професіонал-аматор» у порівняльному аспекті. Теоретично обгрунтовано та емпірично доведено на репрезентативній вибірці із 182 музикантів, що обраний у дослідженні підхід до диференціації ступенів музичної освіти та рівня професіоналізму(в діаді «професіонал-аматор») дозволив виявити розбіжності у психологічних характеристиках музикантів досліджуваних груп. Вивчено стійкі особистісні диспозиційні та динамічні риси, особливості адаптаційного потенціалу, психологічного благополуччя та специфічного емоційного стану «потоку» музикантів.

Встановлено, що музикантам-професіоналам притаманні сміливість, стриманість, схильність до впливу емоцій, допитливість, фрустрованість, в той час як музиканти-аматори характеризуються експресивністю, емоційною стабільністю, сумлінністю, мрійливістю та самодостатністю. Доведено, що музиканти-професіонали $є$ більш схильними до виникнення психоемоційних порушень. Встановлено вищий рівень стану «потоку» у групі музикантів-професіоналів та констатовано його більшу частоту. Проаналізовано специфічність емоційної сфери музикантів-професіоналів і аматорів. Особливі форми вразливості, чуйності, емоційної лабільності сприяють можливості виникнення у групі музикантів-професіоналів психоемоційних порушень різного роду. Завдяки гуманізуючому потенціалу музичної діяльності у музикантів 
виникає можливість із набуттям досвіду переживати стан «потоку», виражаючи негативний емоційний стан шляхом гри на музичному інструменті. Результати дослідження можуть бути використані у психологічній роботі із студентами та педагогами музичних навчальних закладів, а також музикантами-професіоналами із метою покращення їх психологічного здоров'я і благополуччя та попередження виникнення станів психічної дезадаптації.

\title{
PERSONALITY SPECIFICS OF THE PROFESSIONAL MUSICIAN
}

\author{
Arshava I. F. \\ Doctor of Psychological Sciences, Professor, \\ Head of the Department of General Psychology and Pathopsychology \\ Oles Honchar Dnipro National University \\ Haharina Avenue, 72, Dnipro, Ukraine \\ orcid.org/0000-0003-1672-4479 \\ iarshava55@gmail.com \\ Novikov Yu. M. \\ Rector, Professor, Honored Artist of Ukraine \\ Mykhailo Glinka Dnipropetrovsk Academy of Music \\ Lyvarna str., 10, Dnipro, Ukraine
}

Kutepova-Bredun V. Yu.

$P h D$

Associate Professor at the Department of General Psychology and Pathopsychology

Oles Honchar Dnipropetrovsk National University

orcid.org/0000-0002-6137-815X

Haharina Avenue, 72, Dnipro, Ukraine

viluta15@i.ua

Key words: professional and amateur musicians, personality, well-being, the adaptive potential.
The article is devoted to the study of the personal features, psychological well-being, adaptive potential and the state of flow among the professional musicians because every profession requires a person to have certain specific psychological characteristics or qualities, which often directly affect the results of work.

The empirical study, carried out on a representative sample of 182 professional and amateur musicians, has shown that the level of involvement into musical activity influences not only the personality trait characteristics of the participants but also their level of psychological well-being and adaptive abilities.

The hypothesis of the research has been confirmed. The statistically significant difference in several personal traits of professional and amateur musicians has been proved.

The professional musicians in comparison with amateur musicians are prone to autonomy, independency, personal growth, a sense of continuous selfdevelopment and self-perfection with time; they are capable to resist social pressure. At the same time they have higher level of anxiety and aesthetic features as well as low of level of tolerance to unfavorable factors of professional activity particularly under stressful situations. The amateur musicians show a highly developed capacity of socialization, adequate self-appraisal of their role in a group, orientation to maintenance to normative behavior as well as a high 
level of emotional stability in comparison with professional musicians. Our data complement the data of other scholars' data in the aspect of the impact of involvement into musical activity on a psychological well-being of the individuals which has not been studied before. The paradox of psychological well-being with the absence of universally accepted predispositions for it, we describe by the probability of experiencing a state of flow. The results of the research can be used in psychological work with students and teachers of musical educational institutions, as well as the professional musicians, with the aim of improving their psychological health and well-being and preventing the emergence of states of mental disadaptation.

Постановка проблеми. Професійне становлення музиканта-професіонала - це тривалий процес, що включає в себе декілька етапів: навчання у музичній школі, музичному училищі та консерваторії, включаючи при цьому молодший шкільний, іноді, навіть, дошкільний, підлітковий та юнацький періоди, охоплюючи увесь період формування особистості індивіда[6]. На становлення особистості майбутнього музиканта неминуче впливають багаточасові музичні вправи, належність до музичних навчальних закладів, ранні концертні виступи, «викарбовуючи» [4] при цьому іï специфіку та розвиток певних особливостей, таких як експресивність, емоційність, сумлінність, розвиток вольових якостей тощо. Зосереджуючи максимальну кількість уваги на формуванні музичного слуху, технічних аспектах виконання та розвитку спеціальних музичних здібностей, у теперішній час у музичних навчальних закладах ще недостатньо уваги приділяється суто психологічним аспектам формування особистості професіонала та його специфічним проблемам [3; 15].

Завдяки гуманізуючому потенціалу музичної діяльності у музикантів виникає можливість iз набуттям досвіду переживати стан «потоку», виражаючи негативний емоційний стан шляхом гри на музичному інструменті. Творча діяльність створює для музично обдарованої людини можливість вираження засобами музики його душевного стану, пов'язаного як із позитивними, так і з негативними переживаннями, а також надає можливість переживання унікального психічного стану стану «потоку», що виникає за умов досягнення високого рівня майстерної досконалості та надає особі можливість відчувати високий рівень задоволення собою як суб' єктом діяльності. Доступність цього емоційно-сприятливого переживання професіоналу, що має високий рівень майстерності у діяльності, яку виконує щоденно, створює невичерпний ресурс для обдарованої людини відчувати суб'єктивне благополуччя [10; 15$]$.

На думку дослідника Ю.В. Цагареллі, для високої виконавської ефективності музикант повинен мати цілісний комплекс професійно важ- ливих якостей. Серед нейродинамічних, соматичних, загальномузичних здібностей автор виокремив безпосередньо-виконавські якості, структуру яких складають: виконавська техніка, надійність, артистизм музиканта в концертному виступі [5].

Поряд 3 перерахованими вище компонентами професійно-важливих якостей, передумовою успішного формування творчої особистості музиканта, на думку М.В. Нікєшичева, є психологічна схильність виконавця до певного музичного стилю [5].

Науковець J. Shatin, досліджуючи невелику вибірку музикантів, виявив, що музиканти-професіонали $\epsilon$ більш інтелектуальними, схвильовані, ризикованими, чуттевими та самовпевненими у порівнянні із середніми нормами американців [11].

Вчена К.I. Курбатова виокремила комплекс характеристик музично обдарованих підлітків, що відрізняли їх від підлітків із середніми здібностями. Це, на думку автора, інтелектуальні, емоційні та рухово-координаційні характеристики. Інтелектуальний компонент виявляється у тому, що обдаровані підлітки здатні добре структурувати матеріал, логічно мислити, рухово-координаційний - дивергентною взаємодією обох півкуль, відсутністю чіткого домінування однієї 3 рук, та емоційний компонент виражається у емоційній сенситивності. Крім того, здібних до музики підлітків виділяе й прагнення до самоствердження [5].

Як вважає А.Е. Кемп, «музикант - це незалежний та сміливий інтроверт», чутливий та, навіть, тривожний» [12]. Результати досліджень автора вказують на те, що група більш зрілих музикантів-професіоналів у порівнянні 3 контрольною групою має значущо вищий рівень так званої Pathemia (неологізм Кеттелла, що поєднує такі особистісні характеристики як чуттєвість, уяву та інтуїцію), або тип інтуїтивно-чуттєвого сприйняття (за Myers-Briggs). Автор вважає, що Pathemia музикантів пов'язана із сентиментальністю, мрійливістю та емоційним сприйняттям дійсності. Також А.Е. Кемп зазначає на схильність останніх до домінування, уяви, підозрілість 
та значний енергетичний потенціал професійних музикантів [12].

Як вже зазначалося, процес становлення музиканта-професіонала досить довгий і трудомісткий, та може охоплювати 15-16 років (навчання у музичній школі, музичному училищі (коледжі), вищому навчальному музичному закладі (консерваторії) тощо), що включають в себе декілька вікових етапів формування особистості: молодший шкільний, іноді, навіть, дошкільний, підлітковий та юнацький періоди. Згідно культурно-історичної теорії, Л. Виготський називає соціальне середовище не фактором, а джерелом розвитку особистості. У розвитку дитини існує дві взаємопов'язані лінії: природне дозрівання та оволодіння культурними засобами поведінки i мислення. Саме тому ранній початок оволодіння музичною освітою $\epsilon$ вирішальним для формування особистості музиканта [13].

Також існує думка, що музичні здібності виявляються у віці між 2 та 4 роками, але $96.8 \%$ хлопців та $98.7 \%$ дівчат виявляють музичні здібності у віці до 15 років. Особливо важливими у музичному розвитку $є 2$ періоди: шість років, коли у дитини формується здібність концентрувати увагу та період між 9 та 12 роками, коли покращуються як технічні здібності, так і розумові здібності [12].

G. Miller (2000) вказує на те, що музична компетенція, як і інші види діяльності, має стандартний біологічний розклад із сенситивним періодом, після якого музичні навички складніше розвивати. Автор вважає, це вік - близько 7 років. Російська дослідниця Д. Кірнарська вважає, що вік 8 років вирішальний для музичного розвитку. Незважаючи на те, що існує багато винятків серед людей, що розвинули музичні здібності у зрілому віці, більшість науковців вважають, що ранній музичний розвиток $є$ рішучим фактором у формуванні музичних здібностей [13].

Інтеріорізуючись, так звані «натуральні» психічні функції трансформуються та «згортаються», набуваючи автоматизованості, усвідомленості та довільності. Згодом, завдяки цьому алгоритму стає можливим зворотній процес - екстеріоризація - винесення назовні результатів розумової діяльність, що відбувається у внутрішньому плані. Організоване спілкування із дорослим, що і $є$ навчанням, оволодіння інтелектуальною діяльністю, наближують розвиток дитини у музичній діяльності [7].

Початковий рівень оволодіння професією музиканта характеризується тим, що структура емоційної сфери музикантів інтегрована: емоції та якості емоційності пов'язані один із іншим. Під час професіоналізації (на середньому рівні) структура їх інтегрується за групами: властивості емоційності та емоції, що пов'язані із специфікою середнього етапу музичної освіти - поступовістю, поетапністю, стадійністю, що безпосередньо відносяться до емоцій та властивостей емоційності як необхідності їх кращої ідентифікації. Згодом, на вищому рівні професіоналізації, емоційність музиканта інтегрується, формуючи інтегральну емоційну властивість особистості [6].

Структура особистісних властивостей під час оволодіння професією інтегрується. Властивості, що найчастіше проявляються у професійній діяльності, це експресивність як здатність передавати емоційні особливості музичних творів, наполегливість, обов'язковість, сумлінність, самостійність, мрійливість, схильність до фантазування. До особистісних властивостей музикантів дослідниця Д. Кірнарьска відносить підвищений рівень тривоги, критичність, ліберальність, аналітичне, вільне мислення, схильність до групової залежності як повага до інтересів інших, вміння спілкуватися та емоційно проявляти різні настрої, прямолінійність та інші $[9 ; 12]$.

У процесі професіоналізації у музикантів-виконавців домінуючою постає мотивація досягнення успіху, а у більш досвідчених музикантів 3'являється підвищений рівень тривоги [12].

Як вважає Б.А. Бараш, під час вступу до консерваторії абітурієнти мають досить високий рівень професіоналізму (що знову не є характерним для абітурієнтів інших вищих навчальних закладів), але також і недостатню особистісну та емоційну зрілість та дефіцит навичок міжособистісного спілкування [3].

Як було виявлено, значному поширенню нервово-психічних порушень серед студентів консерваторії сприяє досить характерний для останніх тип виховання. Парадокс «виховання музичних вундеркіндів» полягає у тому, що музична діяльність спочатку пасивно нав'язана, згодом часто перетворюється у засіб досягнення професійних навичок та виконавського успіху, але так і не набуває самостійної особистісної значущості [3].

Другим специфічним фактором, який провокує декомпенсації психоемоційного стану у частини студентів, - це відкрита «орієнтація на лауреата». Всі інші студенти продовжують освіту, все більш усвідомлюючи професійні труднощі після закінчення вищих навчальних закладів. Ця система забезпечує відбір найбільш талановитих професіоналів, але не сприяє збереженню психосоматичного здоров'я студентів $[3,4]$. Розподіл учнів на «вищих» та «нижчих», на талановитих та ні, особливо у дитячому віці, гальмує самореалізацію музикантів, спричиняє виникнення неадекватно заниженої самооцінки своїх здібностей та професійних досягнень.

Дослідниці Є.С. Вінокурова та О.О. Блінова підкреслюють, що для досягнення цієї мети необ- 
хідно не лише навчати музикантів-професіоналів та учнів навичкам саморегуляції, що вирішує поточні проблеми, а насамперед формувати у них своєрідну «психологічну культуру», засновану на наукових, а не життєвих знаннях про природу професіоналізму, успіхи та невдачі людини-професіонала [4].

Отже, аналіз наукових досліджень, присвячених вивченню психологічних особливостей музикантів-професіоналів свідчить про обмеженість досліджень цього спрямування у наступних аспектах: відчуття специфічного психоемоційного стану - стану «потоку», специфіки адаптивності та психологічного благополуччя музикантів.

Мета дослідження - емпіричне дослідження специфіки психологічних особливостей музикантів-професіоналів.

Виклад основного матеріалу дослідження. Відповідно до теоретично обгрунтованого уявлення про особистісні особливості особистості музикантів для проведення емпіричного дослідження в якості психодіагностичного інструментарію було обрано: 16-факторний особистісний опитувальник (Р. Кеттел, 1970)- для перевірки особистісних властивостей; методика «Шкала психологічного благополуччя» (SPW, K. Ріфф, 2005) - для діагностики загального рівня психологічного благополуччя та його окремих компонентів; багаторівневий особистісний опитувальник «Адаптивність» (А.Г. Маклаков, С.В. Чермянін, $1993)$ - для визначення особистісного адаптаційного потенціалу та його порушень; методика «Коротка шкала вимірювання стану «потоку» (Ф. Рейнберг, Р. Воллмейер, 2003) - для вивчення специфічного емоційного стану «потоку» у музичній діяльності [14].

Разом у дослідженні взяли участь 182 особи (103 жінки та 79 чоловіків), з яких:
- експериментальна група - музиканти-професіонали (92 особи віком від 18 до 60 років): студенти музичного училища, Дніпровської консерваторії ім. М. Глінки та артисти оркестру Дніпровського драматичного театру ім. Т. Шевченка. Всі представники цієї групи отримали, чи отримують вищу музичну освіту і займаються музичною діяльністю професійно;

- контрольна група - музиканти-аматори (90 осіб), серед яких - студенти Дніпровського національного університету ім. О. Гончара, що займаються музикою непрофесійно (вік від 18 до 24 років), та представники інших професій

Розглянемо результати емпіричного дослідження особистості музикантів-професіоналів та музикантів-аматорів за методикою «16-факторний особистісний опитувальник» Р. Кеттелла. Основні особистісні фактори, які на думку Кеттелла, є стійкими особистісними рисами індивіда, представлені факторами А - О (12 факторів). Статистично значущі розбіжності за показниками методики надаються у таблиці 1. Як видно 3 таблиці 1, статистично значущі розбіжності між результатами у групах досліджуваних були отримані за показниками наступних факторів: $\mathbf{G}$ (низька нормативність поведінки - висока нормативність поведінки), Н (сміливість - боязливість), М (схильність до фантазій - практичність) та О (схильність до почуття провини - самовпевненість).

За фактором G - музиканти-професіонали, схильні до полюса G-, що характеризує їх як індивідів, схильних до впливу емоцій, почуттів, недовірливих, бажаючих не погоджуватися iз загальноприйнятими соціальними нормами. Музиканти-аматори мають показники, що відносять їх до позитивного полюсу - «сумлінність» $(\mathrm{G}+)$ : музиканти-аматори, у порівнянні з музикан-

Таблиця 1

Характер розбіжностей між групами музикантів-професіоналів та музикантів-аматорів за методикою «16-факторний особистісний опитувальник» Р. Кеттелла (R. Cattell, 1970)

\begin{tabular}{|c|l|c|c|c|c|}
\hline $\begin{array}{c}\text { Шифр } \\
\text { шкали }\end{array}$ & \multicolumn{1}{|c|}{ Шкали } & $\begin{array}{c}\text { Музиканти- } \\
\text { професіонали }\end{array}$ & $\begin{array}{c}\text { Музиканти- } \\
\text { аматори }\end{array}$ & $\mathbf{U}_{\text {еми }}$ & $\begin{array}{c}\text { Рівень } \\
\text { значущості } \\
\text { розбіжностей }\end{array}$ \\
\hline $\mathbf{G}$ & $\begin{array}{l}\text { «Слабке Супер-Его - Сильне Супер-Его» } \\
\text { (низька нормативність поведінки - висока } \\
\text { нормативність поведінки) }\end{array}$ & $\mathbf{5 , 1 0 8 6 9 6}$ & $\mathbf{6 , 3 6 9 5 6 5}$ & $\mathbf{7 3 7 , 5}$ & $\mathbf{0 , 0 1 1}$ * \\
\hline $\mathbf{H}$ & $\begin{array}{l}\text { Рагтіа-Тhrестіа } \\
\text { (сміливість - боязливість) }\end{array}$ & $\mathbf{6 , 1 5 2 1 7 4}$ & $\mathbf{5 , 2 3 9 1 3}$ & $\mathbf{7 1 5 , 5}$ & $\mathbf{0 , 0 4 6 *}$ \\
\hline $\mathbf{M}$ & $\begin{array}{l}\text { Аутія - праксернія } \\
\text { (сильність до фантазій - практичність) }\end{array}$ & $\mathbf{5 , 4 5 6 5 2 2}$ & $\mathbf{6 , 0 2 1 7 3 9}$ & $\mathbf{7 0 3 , 5}$ & $\mathbf{0 , 0 2 1 *}$ \\
\hline $\mathbf{O}$ & $\begin{array}{l}\text { Гіпотимія - Гіпертимія } \\
\text { (схильність до почуття провини - } \\
\text { самовпевненість) }\end{array}$ & $\mathbf{7 , 5}$ & $\mathbf{6 , 1 9 5 6 5 2}$ & $\mathbf{7 2 0}$ & $\mathbf{0 , 0 0 8 * *}$ \\
\hline $\mathbf{Q 2}$ & самодостатність - соціабельність & $\mathbf{4 , 6 7 3 9 1 3}$ & $\mathbf{6 , 9 5 6 5 2 2}$ & $\mathbf{5 3 9 , 5}$ & $\mathbf{0 , 0 0 1 * *}$ \\
\hline $\mathbf{Q 4}$ & фрустрованість - нефрустрованість & $\mathbf{6 , 9 3 4 7 8 3}$ & $\mathbf{5 , 4 7 8 2 6 1}$ & $\mathbf{7 0 9}$ & $\mathbf{0 , 0 0 6 * *}$ \\
\hline
\end{tabular}


тами-професіоналами, проявляють більшу відповідальність, врівноваженість, мають розвинене почуття обов'язку і відповідальності, усвідомлено дотримуються загальноприйнятих моральних правил і норм, наполегливі у досягненні мети, їм притаманні ділова спрямованість, схильність до співпраці і конформізму.

Згідно отриманих результатів, музиканти-професіонали, у порівнянні із музикантами-аматорами, мають також вищий рівень сміливості $(\mathrm{H}+)$, винахідливості, активності, готовності до ризику та співпраці із незнайомими. Останні здатні до прийняття самостійних, неординарних рішень, схильні до авантюризму та прояву лідерських якостей.

За результатами дослідження, представленими у таблиці 1, існують також статистично значущі розбіжності між результатами у групах музикантів-професіоналів та музикантів-аматорів за фактором М. Отримані дані вказують на те, що у порівнянні $з$ музикантами-професіоналами, особи, які захоплюються музикою на аматорському рівні, демонструють значно вищі показники за фактором М+ (аутія, мрійливість), що проявляється у наявності багатої уяви, внутрішніх ілюзій, уміння оперувати абстрактними поняттями, орієнтованості на свій внутрішній світ.

За фактором О (Гіпотимія-Гіпертимія) обидві групи відносяться до полюсу $\mathrm{O}+$, що характеризує представників обох груп як осіб, схильних до почуття провини, тривоги та передчуттів, занепокоєності, стурбованості, пригніченості, але статистичні розбіжності між показниками обох груп вказують на те, що всі ці характеристики притаманні музикантам-професіоналам у більшому ступені.

Динамічні риси музикантів-професіоналів та музикантів-аматорів, досліджені за допомогою 16-факторного опитувальника Кеттелла, представлені факторами $\mathrm{Q}_{1}-\mathrm{Q}_{4}$. Як можна побачити iз таблиці, статистично значущі розбіжності встановлено за факторами $\mathrm{Q}_{2}$ та $\mathrm{Q}_{4}$ Статистично значущі розбіжності за фактором $\mathrm{Q}_{2}$ вказують на те, що у музикантів-професіоналів за результатами даної методики наявною є така риса, як «залежність від групи» $\left(\mathrm{Q}_{2}\right)$, у той час як музиканти-аматори (за результатами методики) є більш самодостатніми $\left(\mathrm{Q}_{2}+\right)$, незалежними від групи та самостійними.

Статистичні розбіжності у групах за фактором $\mathrm{Q}_{4}$ (напруженість) свідчать на користь того, що музикантам-професіоналам притаманний більш високий рівень фрустрованості, занепокоєння, заклопотаності, іпохондричності, схильність до змін настрою, депресії, наявність страху, невпевненості у собі, чутливості до критики оточуючих. Високі показники за фактором $\mathrm{Q}_{4}+$ (напруженість) інтерпретуються також як енергетична схвильованість, яка вимагає певної розрядки, бо цей стан може перетворитися на психосоматичний розлад у зв'язку зі зниженням рівня емоційної стійкості, порушенням рівноваги, а також, можливо, і прояву агресивності. Можна припустити, що музичне мистецтво слугує професіоналам джерелом, що сприяє зменшенню напруженості та фрустрованості їх тонкої душевної організації. Музикантиаматори, у порівнянні із професіоналами, є більш розслабленими, спокійними, стриманими, навіть апатичними. Слід зазначити, що якщо вищезазначені характеристики не досягають клінічного рівня вираженості, то вони можуть надавати музикантам значної мотивації щодо досягнень та високу ефективність у навчанні і професії, а також виступати у якості стимулу для отримання інших творчих досягнень.

Особливості перебігу психічних станів музикантами-професіоналами та музикантами-аматорами були досліджені за допомогою методики «Багаторівневий особистісний опитувальник «Адаптивність» А. Г. Маклакова та С. В. Чермяніна (1993).

У таблиці 2 представлено опис статистично значущих розбіжностей за результатами методики «Багаторівневий особистісний опитувальник «Адаптивність» між групами музикантів-професіоналів та музикантів-аматорів. Статистично

Таблиця 2

Характер розбіжностей між групами музикантів-професіоналів та музикантів-аматорів за методикою «Багаторівневий особистісний опитувальник «Адаптивність»

(А.Г. Маклаков, С.В. Чермянін, 1993)

\begin{tabular}{|l|c|c|c|c|}
\hline \multicolumn{1}{|c|}{ Шкали } & $\begin{array}{c}\text { Музиканти- } \\
\text { професіонали }\end{array}$ & $\begin{array}{c}\text { Музиканти- } \\
\text { аматори }\end{array}$ & $\mathbf{U}_{\text {емп }}$ & $\begin{array}{c}\text { Рівень значущості } \\
\text { розбіжностей }\end{array}$ \\
\hline Поведінкова регуляція & 3,855 & 3,576 & 1532,5 & 0,117 \\
\hline Комунікативний потенціал & 4,113 & 4,288 & 1824 & 0,979 \\
\hline Моральна нормативність & $\mathbf{4 , 4 0 3}$ & $\mathbf{5 , 4 4 1}$ & $\mathbf{1 2 2 0}$ & $\mathbf{0 , 0 0 1 * *}$ \\
\hline Астенічні стани & $\mathbf{3 , 5 8 1}$ & $\mathbf{4 , 0 5 1}$ & $\mathbf{1 3 8 5}$ & $\mathbf{0 , 0 1 2 *}$ \\
\hline Психотичні стани & 3,952 & 3,898 & 1728 & 0,582 \\
\hline Дезадаптивні розлади & 3,952 & 3,746 & 1541,5 & 0,119 \\
\hline
\end{tabular}


значущі розбіжності було визначено за шкалами «Моральна нормативність» та «Астенічні стани».

Із таблиці 2 можна побачити, що музикантиаматори, у порівнянні з музикантами-професіоналами, мають значущо вищий рівень моральної нормативності, що забезпечує здатність індивіда адекватно сприймати пропоновану для нього певну соціальну роль. Рівень моральної нормативності індивіда відображає два основні компоненти процесу соціалізації: сприйняття морально-етичних норм поведінки і відношення до вимог безпосереднього соціального оточення. Музиканти-аматори ж мають більшу схильність до виникнення астенічних станів, ніж музиканти-професіонали.

За результатами, що були отримані при обстеженні музикантів двох груп за методикою «Шкала психологічного благополуччя» К. Ріфф, статистично значущі розбіжності було виявлено за шкалами «Автономія» та «Особистісний ріст», що, відповідно, вплинуло і на результати загального рівня психологічного благополуччя. 3 таблиці 3 можна побачити, що музиканти-професіонали мають вищий рівень за вказаними шкалами.

Отже, згідно даних, отриманих у дослідженні за допомогою методики «Шкала психологічного благополуччя» було встановлено, що музиканти-професіонали, у порівнянні із музикантами-аматорами $\epsilon$ більш незалежними, здібними протистояти соціальному тиску у своїх думках i діях та регулювати поведінку в залежності від своїх стандартів. Також їм притаманне почуття безперервного саморозвитку, самовдосконалення, осмисленості життя та почуття реалізації свого потенціалу. Високі показники за цими шкалами вплинули на значущо вищий інтегральний показник загального рівня психологічного благополуччя музикантів-професіоналів.

Результати, отримані за методикою «Коротка шкала вимірювання стану потоку» (Ф. Рейнберг, Р. Уоллмер, 2003) свідчать про те, що не існує статистично значущих розбіжностей між групами за показниками загального рівня стану «потоку» та «занурення у діяльність», хоча представники групи музикантів-професіоналів й мають дещо вищий рівень відчуття стану «потоку», що не досягає рівня статистичної значущості. Рівень особистісної значущості музичної діяльності $\left(\mathbf{U}_{\text {eмп }}=292,5\right.$, $\mathrm{p} \leq \mathbf{0 , 0 1 9 )}$ є вищим для музикантів-професіоналів, що є очікуваним, так як музична діяльність для останніх $є$ основним видом діяльності, у той час як для музикантів-аматорів музична діяльність - захоплення, спосіб проведення вільного часу. Також статистично значущі розбіжності виявилися за показниками шкали «досконалості» як компоненту стану «потоку» $\left(\mathbf{U}_{\text {емп }}=322,5\right.$, $\mathrm{p} \leq \mathbf{0 , 0 3 9 )}$. Це свідчить про те, що захоплення музичною діяльністю відчувається музикантами-професіоналами плавно, безперервно, що $\epsilon$ можливим лише за умов досягнення особами високого рівня музичних вмінь та навичок.

Висновки. При аналізі результатів дослідження щодо виявлення психологічної специфіки музикантів-професіоналів було встановлено, що музикант є особливою особистістю, має тонку та складну душевну організацію і тому потребує психологічного супроводу на протязі всього періоду навчання та діяльності, що сприятиме попередженню виникнення різного роду психоемоційних порушень та станів декомпенсації. Як свідчать результати емпіричного дослідження, музиканти-професіонали мають вищий рівень переживання «стану потоку», та музична діяльність має дуже важливу роль у їх житті, що підтверджується і значно вищими показниками за шкалою «особистісна значущість діяльності». Крім того психологічною специфікою музикантів-професіоналів $\epsilon$ наявність таких рис як стриманість, сміливість, схильність до впливу емоцій. Подальші дослідження обраної проблеми ми пов' язуємо із розробкою системи психопрофілактичних та психокорекційних засад для музикантів різного віку та спеціалізації з метою попередження виникнення станів психічної дезадаптації музикантів.

Таблиця 3

Характер розбіжностей між групами музикантів-професіоналів та музикантів-аматорів за методикою «Шкала психологічного благополуччя» (К. Ріфф, 2005)

\begin{tabular}{|l|c|c|c|c|}
\hline \multicolumn{1}{|c|}{ Шкали } & $\begin{array}{c}\text { Музиканти- } \\
\text { професіонали }\end{array}$ & $\begin{array}{c}\text { Музиканти- } \\
\text { аматори }\end{array}$ & $\mathbf{U}_{\text {емп }}$ & $\begin{array}{c}\text { Рівень значущості } \\
\text { розбіжностей }\end{array}$ \\
\hline Позитивні відносини з оточуючими & 59,532 & 61,017 & 1536 & 0,128 \\
\hline Автономія & 59,290 & 54,525 & $\mathbf{1 2 2 7}$ & $\mathbf{0 , 0 0 2 *}$ \\
\hline Управління середовищем & 58,306 & 56,576 & 1710 & 0,537 \\
\hline Особистісний ріст & 67,065 & 60,390 & $\mathbf{9 7 6}$ & $\mathbf{0 , 0 0 0 1 * *}$ \\
\hline Цілі у житті & 64,823 & 62,763 & 1598 & 0,31 \\
\hline Самосприйняття & 56,081 & 52,627 & 1547 & 0,143 \\
\hline $\begin{array}{l}\text { Загальний рівень психологічного } \\
\text { благополуччя }\end{array}$ & 370,097 & 345,898 & $\mathbf{1 0 1 9}$ & $\mathbf{0 , 0 0 1}$ \\
\hline
\end{tabular}




\section{ЛІТЕРАТУРА}

1. Аршава І. Ф. Особистісні характеристики музикантів-професіоналів та музикантів-аматорів / І.Ф. Аршава, Е.Л. Носенко, В.Ю. Кутєпова-Бредун. Актуальні проблеми психології: збірник наукових праць Інституту психології імені Г.С. Костюка НАПН України. Т. VI: Психологія обдарованості. Випуск 11. Київ-Житомир: Вид-во ЖДУ ім. І. Франка. 2015. № 11. 2015. С. 20-30.

2. Психологія музиканта-виконавця: Монографія / І.Ф. Аршава, В.Ю. Кутєпова-Бредун. - Д. «А.Л. Свідлер», 2020. 168 с.

3. Бараш Б. А. Психопрофилактическая помощь студентам вузов. Психогигиена и психопрофилактика. Л., 1983. С. 39-45.

4. Блинова О. А. Личностно-ориентированные тренинги творческой самореализации для музыкантов-профессионалов. Музыкальное творчество на рубеже третьего тысячелетия: тезисы международной научно-практической конференции. Астрахань, 2001. С. 192-194.

5. Ильин Е. П. Психология творчества, креативности, одаренности. СПб.: Питер. 2009. 448 с.

6. Кирнарская Д. К. Психология специальных способностей. Музыкальные способности. М.: Таланты - XXI век, 2004. 496 с.

7. Моляко В. О. Психологія творчості - нова парадигма дослідження конструктивної діяльності людини. Практична психологія та соціальна робота. 2004. № 8. С. 1-4.

8. Arshava I. F. The comparison of personal traits of the professional and amateur musicians / I.F. Arshava, V.Y. Kutepova-Bredun / European Scientific Journal. ESJ. 2015. Vol. 11. № 20. P. 46-55.

9. Arshava I. The specifics of psychological well-being of the professional and amateur musicians / I. F. Arshava, V. Kutepova-Bredun / Quare 2018, 18-22.06.18, The Chech Republic, 2018. P. 6.

10. Csikszentmihalyi M. Beyond Boredom and Anxiety: Experiencing Flow in Work and Play. San Francisco. CA: Jossey-Bass, 2000.

11. Kemp A. Personality differences between the players of string, woodwind, brass and keyboard instruments and singers. Bulletin of the Council for Research in Music Education, 1981. p. 33-38.

12. Kemp A. The musical temperament: Psychology and personality of musicians. Oxford, England: Oxford University Press, 1996.

13. Kirnarskaya D. The natural musician: On abilities, giftedness and talent. Oxford: Oxford University Press, 2011.

14. Rheinberg F. Die Erfassung des Flow-Erlebens. The assessment of flow experience, in J. StiensmeierPelster and F. Rheinberg (Eds.), Diagnostic von Motivation und Selbstkonzept / F. Rheinberg, R. Vollmeyer, S. Engeser. Gottingen: Hogrege. 2003. P. 261-279.

15. Seligman M.E. Positive psychology: An introduction. Amarican Psychologist / M.E. Seligman, M. Csikszentmihalyi. 55 (1). P. 5-14.

16. Seligman M. Flourish: A Visionary New Understanding of Happiness and Wellbeing. 2011. New York: Free Press.

\section{REFERENCES}

1. Arshava I. F. (2015) Osobystisni kharakterystyky muzykantiv-profesionaliv ta muzykantiv-amatoriv [Personal characteristics of professional musicians and amateur musicians]. Kyiv-Zhytomyr: [in Ukrainian]

2. Arshava I. F., Kutepova-Bredun. The comparison of personal traits of the professional and amateur musicians. European Scientific Journal. ESJ. [in English]

3. Arshava I.F., Kutiepova-Bredun V.Iu. (2020) Psykholohiia muzykanta-vykonavtsia: Monohrafiia/ [Psychology of a musician-performer:monography] Dnipro. «A.L. Svidler». [in Ukrainian].

4. Arshava I., Kutepova-Bredun V. (2018) The specifics of psychological well-being of the professional and amateur musicians.Quare, 18-22.06.18, The Chech Republic.

5. Barash B.A. (1983) Psykhoprofylaktycheskaia pomoshch studentam vuzov [Psychoprophylactic assistance to university students]. Leningrad. [in Russian]

6. Blynova O. A. (2001) Lychnostno-oryentyrovannue trenynhy tvorcheskoi samorealyzatsyy dlia muzukantov-professyonalov [Personally-oriented trainings of creative self-realization for professional musicians]. Astrakhan. [in Russian]

7. Csikszentmihalyi M. (2000) Beyond Boredom and Anxiety: Experiencing Flow in Work and Play. San Francisco. CA: Jossey-Bass. [in English]

8. Kemp A. (1981) Personality differences between the players of string, woodwind, brass and keyboard instruments and singers. Bulletin of the Council for Research in Music Education. [in English]

9. Kemp A. (1996) The musical temperament: Psychology and personality of musicians. Oxford, England: Oxford University Press. 
10. Kirnarskaya D. (2011) The natural musician: On abilities, giftedness and talent. Oxford: Oxford University Press. [in English]

11. Kyrnarskaia D. K. (2004) Psykholohyia spetsyalnukh sposobnostei [Psychology of special abilities]. M.: Talantu.

12. Moliako V. O. (2004) Psykholohiia tvorchosti - nova paradyhma doslidzhennia konstruktyvnoi diialnosti liudyny [Psychology of creativity - a new paradigm for the study of constructive human activity].

13. Rheinberg F. Die Erfassung des Flow-Erlebens.( 2003) The assessment of flow experience, in J. Stiensmeier-Pelster and F. Rheinberg (Eds.), Diagnostic von Motivation und Selbstkonzept / F. Rheinberg, R. Vollmeyer, S. Engeser. Gottingen: Hogrege. P. 261-279.

14. Seligman M. (2011) Flourish: A Visionary New Understanding of Happiness and Wellbeing. New York: Free Press.

15. Seligman M.E. (2000) Positive psychology: An introduction. Amarican Psychologist / M.E. Seligman, M. Csikszentmihalyi. 55 (1). P. 5-14.

16. Ylyn E. P. (2009) Psykholohyia tvorchestva, kreatyvnosty, odarennosty [Psychology of creativity, creativity, giftedness]. SPb.: Pyter. [in Russian]. 